\title{
Influence of Monocropping Brown Stem Rot-Resistant and -Susceptible Soybean Accessions on Soil and Stem Populations of Phialophora gregata f. sp. sojae
}

\author{
T. J. Hughes, N. C. Koval, P. D. Esker, and C. R. Grau, Department of Plant Pathology, University of Wisconsin- \\ Madison, Madison 53706
}

\begin{abstract}
Hughes, T. J., Koval, N. C., Esker, P. D., and Grau, C. R. 2009. Influence of monocropping brown stem rot-resistant and -susceptible soybean accessions on soil and stem populations of Phialophora gregata f. sp. sojae. Plant Dis. 93:1050-1058.

Brown stem rot (BSR)-resistant and -susceptible soybean accessions were continuously cropped in an area never previously seeded to soybean to study the influence of monocultures on soil and stem populations of Phialophora gregata f. sp. sojae. P. gregata f. sp. sojae population size and genotype composition were determined by dilution plating, isolation of $P$. gregata $\mathrm{f}$. sp. sojae and standard polymerase chain reaction (PCR), and by quantitative real-time PCR (q-PCR. In general, the sizes of $P$. gregata f. sp. sojae populations in soil were similar regardless of monoculture. The percentage of $P$. gregata f. sp. sojae genotype B was greater than A in soil following the monoculture of both BSR-susceptible and -resistant soybean accessions. Following the monoculture of a BSR-resistant accession, the percentage of $P$. gregata f. sp. sojae genotype B was greater than A. Overall, $P$. gregata $\mathrm{f}$. sp. sojae populations in stems of a BSR-susceptible accession were greater than those in stems of a BSR-resistant accession. P. gregata f. sp. sojae genotype B was detected more often than A in stems of both resistant and susceptible accessions planted following a BSR-resistant monoculture. P. gregata f. sp. sojae genotype B was also detected more often than A in stems of a BSR-resistant accession planted following a BSRsusceptible monoculture. P. gregata f. sp. sojae genotypes A and B were isolated at similar frequencies from stems of a BSR-susceptible accession planted following a BSR-susceptible monoculture. However, q-PCR results indicate that the percentage of $P$. gregata $\mathrm{f}$. sp. sojae genotype A was greater than B in stems of a BSR-susceptible accession planted following a BSR-susceptible monoculture. Among BSR-susceptible accessions, those with the soybean cyst nematode (SCN)-resistant cv. Peking in their parentage had the largest populations of $P$. gregata f. sp. sojae and a greater percentage of $P$. gregata f. sp. sojae genotype B. Similar results were observed for BSR-resistant accessions derived from SCN-resistant PI 88788.
\end{abstract}

Brown stem rot (BSR) is a chronic disease of soybean (Glycine max (L.) Merr.) throughout much of the north-central United States (36). Methods of controlling BSR are limited to crop rotations of 3 to 5 years $(5,11,22)$, soil tillage $(5,35)$, and host resistance $(5,20,33)$. These methods have mitigated yield loss due to BSR but are nonsustainable solutions for several reasons. The majority of soybean acres in the United States are in reduced- or no-till systems and soybean is often grown in an annual rotation with corn. Cultivars with resistance to BSR are derived from a narrow genetic base and are classified as resistant based on a reduction in symptom severity $(7,20,27)$ and not by the prevention or restriction of pathogen colonization $(8,21,23)$.

The causal agent of BSR, Phialophora gregata f. sp. sojae K. Kobay., Hid. Ya-

Corresponding author: T. J. Hughes

E-mail: tjh@plantpath.wisc.edu

Accepted for publication 4 July 2009.

doi:10.1094/PDIS-93-10-1050

(C) 2009 The American Phytopathological Society mam., Negishi \& Ogoshi (syn. Cadorphora gregata [15] and Cephalosporium gregatum), is a residue-borne fungal pathogen that survives saprophytically from season to season in host tissue colonized during its parasitic phase $(4,21)$. Isolates of $P$. gregata $\mathrm{f}$. sp. sojae can be separated into two genotypes, A and B, based on an insertion or deletion (INDEL) in the intergenic spacer region (IGS) of ribosomal DNA (8). These two genotypes are sympatric and are found throughout the north-central United States $(8,23)$. Additional genetic studies confirm that genotypes A and B are of the same species but have evolved independently and do not show evidence of gene flow $(9,16)$.

The classification of isolates of $P$. gregata f. sp. sojae as genotype A or B corresponds to differences in symptom expression by infected soybean plants $(16,19)$. In general, isolates of genotype A are considered more aggressive than genotype B, causing more severe foliar symptoms on BSR-susceptible cultivars. Studies by Chen et al. (8), Malvick et al. (23), and Meng et al. (25) also suggest that soybean cultivars are preferentially colonized by isolates of genotype A and B. Cultivars classified as resistant to BSR were colo- nized more frequently by $P$. gregata $\mathrm{f}$. sp. sojae genotype $\mathrm{B}$ than genotype $\mathrm{A}$, whereas cultivars susceptible to BSR were colonized more frequently by $P$. gregata $\mathrm{f}$. sp. sojae genotype A than genotype B.

The genetics of the soybean cultivar also appears to influence the frequency of $P$. gregata $\mathrm{f}$. sp. sojae genotype recovered from soybean stems $(8,23)$. The ratio of genotype B to genotype A was 2:1 for BSR-resistant cultivars containing one or more reported $R b s$ genes $(12,14)$. For BSR-resistant cultivars derived from plant introduction (PI) 88788 (20,29), the ratio of genotype B to A was 9:1. For BSRsusceptible soybean cultivars, the ratio of genotype A to genotype B was 1:1 for cultivars with the BSR-susceptible cv. Sturdy in their parentage while the ratio of A to B was $4: 1$ for those with the BSRsusceptible cv. Century 84 in their parentage $(8,23)$.

Differences between $P$. gregata f. sp. sojae genotypes $\mathrm{A}$ and $\mathrm{B}$ for aggressiveness $(16,19)$ and host colonization $(8,23)$ could critically influence how we understand and approach control of BSR. Prior to the identification of $P$. gregata $\mathrm{f}$. sp. sojae genotypes, Tachibana et al. (34) reported that continuous cropping of cultivars resistant to BSR would provide the same level of disease control as crop rotation with a nonhost. In this study, BSR-susceptible cultivars showed a decrease in disease incidence and severity following a 4-year monoculture of a BSR-resistant cultivar compared with the same cultivars planted following the monoculture of a BSRsusceptible cultivar. From these results, Tachibana et al. (34) proposed that the decrease in BSR incidence and severity was due to a decrease in the propagules of $P$. gregata f. sp. sojae in host residue. Based on the current understanding of the soybean-P. gregata f. sp. sojae interaction, these results may have been due to a change in the genotypic structure of $P$. gregata $\mathrm{f}$. sp. sojae rather than the inoculum concentration.

The interaction between soybean genotype and $P$. gregata f. sp. sojae genotype is not fully understood and current information is based solely on stem populations of P. gregata f. sp. sojae $(4,8,16,23)$. P. gregata f. sp. sojae infects soybean plants shortly after germination through the main and lateral roots $(2,13)$, and the density of $P$. gregata f. sp. sojae populations at planting has been shown to be positively corre- 
lated to BSR development (3). In addition, Bachman and Nickell (7), through reciprocal grafting experiments, provided evidence that the morphological location of the resistance response may be in the soybean root. Therefore, it is necessary to determine the influence of host genotype on populations of $P$. gregata f. sp. sojae in the soil. Recently, quantitative real-time polymerase chain reaction (q-PCR) assays have been developed that are capable of quantifying populations of $P$. gregata $\mathrm{f}$. sp. sojae and differentiating between genotypes A and B in both plant and soil samples $(18,24)$. These assays provide a necessary tool for studying soil populations of $P$. gregata f. sp. sojae.

With an improved understanding of the soybean- $P$. gregata $\mathrm{f}$. sp. sojae interaction in both the plant and soil environments, we can improve the efficacy and sustainability of BSR control. To this effect, a multiyear experiment was established in a location with no history of soybean or BSR. Soybean accessions varying in their genetic resistance or susceptibility to BSR were continuously cropped for 5 years in the same location, establishing monocultures based on known host genetics. The objective of this study was to determine the influence of BSR-resistant and -susceptible soybean monoculture on the size and genotype composition of $P$. gregata $\mathrm{f}$. sp. sojae populations in both stems and soil.

\section{MATERIALS AND METHODS}

Field preparation. In 2000, a field site was established at the Arlington Agricultural Research Station, Arlington, WI, which had been previously planted to pea (Pisum sativum), a nonhost of Phialophora gregata f. sp. sojae (6). The field site had never been seeded to soybean and did not have a known history of BSR or P. gregata f. sp. sojae. Soil was a Plano silt loam with a $\mathrm{pH}$ range from 6.1 to 6.4 . In each year of this study (2000 through 2005), the field site was chisel plowed in the fall and spring. Herbicides were applied for weed control either before planting or before planting and again post emergence as follows: in 2000, Dual (Ciba-Geigy Corp., Greensboro, NC; preplant, 2.3 liter/ha), Basagran, and Poast (BASF, Wyandotte,
MI; post emergence, 2.3 liter/ha and 42.5 $\mathrm{g} / \mathrm{ha}$, respectively); in 2001, Dual (preplant), Pinnacle (DuPont, Mississauga, ON, Canada; post emergence, $7 \mathrm{~g} / \mathrm{ha}$ ), and FirstRate (Dow AgroSciences, Indianapolis, IN; post emergence, $8.5 \mathrm{~g} / \mathrm{ha}$ ); in 2002, Lasso (Monsanto, St. Louis; preplant, 4.7 liter/ha), Pinnacle, FirstRate, and Poast (post emergence); and in 2003 through 2005, Dual (preplant) and FirstRate (preplant; $21.2 \mathrm{~g} / \mathrm{ha}$ ).

Field design and layout. Ten soybean accessions were selected based on their genetic resistance or susceptibility to BSR (Table 1). Each accession was planted in 38-by-9-m plots consisting of 12 rows ( 3 border rows on each side and 6 center test rows) spaced $0.8 \mathrm{~m}$ apart and arranged in a randomized complete block design (RCBD) with four replications. Plots were planted 16 May 2000, 9 May 2001, 15 May 2002, 22 May 2003, 4 June 2004, and 5 May 2005 at a rate of 30 seeds $/ \mathrm{m}$ of row using a John Deere (Moline, IL) flex planter (2000 and 2001) or Tye (AGCO Corp., Duluth, GA) no-till drill (2002 through 2005). At maturity (soybean growth stage R8; 30), test rows were harvested with an Almaco (Nevada, IA) plot combine and evaluated for yield. Harvest dates were 18 October 2000, 16 October 2001 through 2003, 11 October 2004, and 5 October 2005. Monocultures were established by planting the same soybean accession in the same field location from 2000 through 2004 (Fig. 1).

Plots were assessed each year for BSR foliar symptom severity at late pod-fill (R6) by visually estimating the percentage of the test row canopy expressing foliar symptoms characteristic of BSR and assigning a Horsfall-Barratt (HB) rating (17). Additionally, from 2002 through 2004, 10 plants at beginning maturity (R7), were arbitrarily selected within the test rows and assessed for internal symptoms by longitudinally splitting stems and visually estimating the percentage of vascular and pith tissue discoloration and assigning an $\mathrm{HB}$ rating.

In 2005 , the direction of planting was rotated $90^{\circ}$ and the size of each plot reduced to 3-by-9-m plots consisting of four rows each (one border row on each side

Table 1. Soybean accessions grown from 2000 through 2005 at Arlington, WI

\begin{tabular}{|c|c|c|c|}
\hline Accession & BSR rxn ${ }^{\mathrm{a}}$ & BSR-R source, gene $^{\mathrm{b}}$ & BSR-S soybean accession in parentage \\
\hline BSR 101 & $\mathrm{R}$ & $R b s 1,3$ & $\cdots$ \\
\hline IA $2008 \mathrm{R}$ & $\mathrm{R}$ & Rbs 1,3 & $\ldots$ \\
\hline LN92-120334 & $\mathrm{R}$ & $R b s 2$ & $\ldots$ \\
\hline Dwight & $\mathrm{R}$ & PI 88788 & 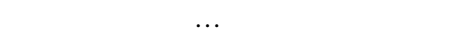 \\
\hline Jack & $\mathrm{R}$ & PI 88788 & $\ldots$ \\
\hline Sturdy & $\mathrm{S}$ & $\ldots$ & Century \\
\hline Corsoy 79 & $\mathrm{~S}$ & $\ldots$ & Corsoy \\
\hline Hardin & $\mathrm{S}$ & $\ldots$ & Corsoy \\
\hline Pioneer 9234 & $\mathrm{~S}$ & $\ldots$ & Peking \\
\hline Williams 82 & $\mathrm{~S}$ & $\ldots$ & Peking \\
\hline
\end{tabular}

${ }^{a}$ Reaction of soybean accession to brown stem $\operatorname{rot}(\mathrm{BSR}) ; \mathrm{R}=$ resistant and $\mathrm{S}=$ susceptible.

${ }^{b}$ Gene conferring resistance or source (plant introduction [PI]) used to attain resistance to BSR. and two center test rows). The change in direction of planting and the reduction in plot size allowed each accession to be planted in an area previously planted to itself, as well as that of the nine other accessions in each of the four replicated blocks (Fig. 1). BSR symptom severity was assessed as previously described with the following modifications. BSR foliar symptoms were assessed periodically from early flowering (R1) to late pod-fill (R6). Ratings were then used to calculate area under disease progress curves (AUDPCs) (26). At beginning maturity (R7), 15 plants per plot were arbitrarily selected from within the test rows and incidence of internal symptoms was determined as the percentage of stems that expressed symptoms of BSR.

Soil samples for q-PCR. Soil samples were collected in spring in order to assess populations of $P$. gregata f. sp. sojae following five consecutive years of the same soybean accession and to determine the genotype composition of the inoculum present for the 2005 growing season. On 17 June 2005, three soil cores, $2.54 \mathrm{~cm}$ in diameter, were collected to a depth of ap-

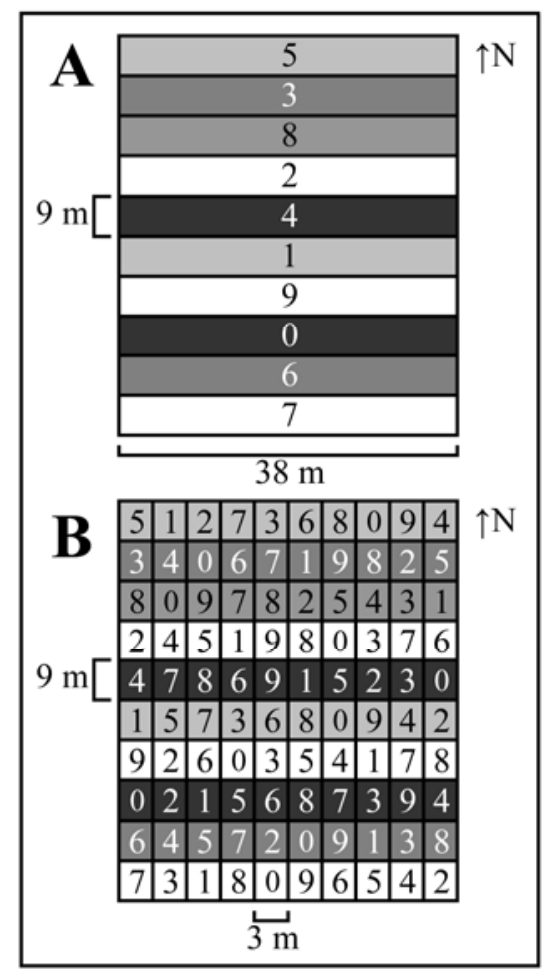

Fig. 1. Field design and layout for studying the influence of monocropping brown stem rot (BSR)-resistant (0 to 4) and BSR-susceptible (5 to 9) soybean accessions on stem and soil populations of Phialophora gregata f. sp. sojae. A, Field design from 2000 through 2004 in which accessions were planted continuously in the same location in each year. B, Field design for 2005 in which the direction of planting was rotated $90^{\circ}$ and the plot size reduced so that each accession was planted onto the monoculture of itself as well as that of the other nine accessions. Figure depicts one of four replications at Arlington, WI. 
proximately 8 to $10 \mathrm{~cm}$ from within each plot and stored at $-20^{\circ} \mathrm{C}$ until processing. To account for the change in the direction of planting and planting error, the location of each soil core was randomly selected as follows. Within each 3-by-9-m plot, internal borders were established such that the sampling area within each plot measured 1.8 by $7.9 \mathrm{~m}$. Within this area, coordinates for each soil sample were determined by randomly generating a number between 0 and 1 using the uniform random data calculator in Minitab 14 statistical software (State College, PA), and multiplying one randomly generated number by 1.8 (width of plot) and another by 7.9 (length of plot). Sample locations were the two randomly generated numbers rounded to the nearest whole number. Three sets of coordinates were generated to collect 30 cores per accession per replicate for an experiment total of 1,200 soil cores (Fig. 1).

Soil cores were individually air dried and pulverized with a rubber mallet. Soil $(1 \mathrm{~g})$ from each of the pulverized cores was added to a 2-ml microcentrifuge tube provided with the MoBio (Carlsbad, CA) UltraClean Soil DNA extraction kit. Samples were stored at $-80^{\circ} \mathrm{C}$ until processing as suggested by the manufacturer. Total genomic DNA was extracted by using the UltraClean Soil DNA extraction kit and the MoBio Vortex Adaptor tube holder according to the manufacturer's alternative protocol for maximum DNA yields. Inhibitors to PCR were removed during extraction using the inhibitor removal solution (IRS) provided with the kit. DNA concentrations were determined and concentrations standardized $(1 \mathrm{ng} / \mu \mathrm{l})$ with ultrapure molecular grade water.

Stem samples for dilution plating, isolate collection, and isolate genotyping. The 15 plants collected at beginning maturity (R7) in 2005 were bulked into five groups of three plants each and allowed to air dry. For each bulk sample, approximately 13 to $15 \mathrm{~cm}$ of the lower stem was ground, initially through a Wiley Mill (Thomas Scientific, Swedesboro, NJ) fitted with a $0.5-\mathrm{mm}$ sieve, followed by a secondary grinding through a Cyclone Sample Mill (Udy Corp., Fort Collins, CO) $(5,19)$. Mills were cleaned between bulked groups with pressurized air or vacuum. Ground tissue from each bulk was dilution plated onto a semiselective medium (28) and incubated in the dark at $12^{\circ} \mathrm{C}$ for 4 weeks. Following incubation, colonies of $P$. gregata f. sp. sojae were counted and the number of CFU per gram of tissue was calculated $(3,21,28)$.

Colonies of $P$. gregata f. sp. sojae were arbitrarily selected from each of the dilution plates and transferred onto quarterstrength potato dextrose agar (PDA) $(25 \mathrm{~g}$ of peeled, sliced potato tubers, $1.25 \mathrm{~g}$ of dextrose, $7.5 \mathrm{~g}$ of agar, and $500 \mathrm{ml}$ of deionized water) and incubated at room temperature for 5 to 7 days. A total of five pure-culture isolates of $P$. gregata f. sp. sojae per plot (2,000 possible) were selected and subsequently transferred onto full-strength PDA and incubated at room temperature for 2 weeks. Subcultures of each isolate were transferred to glass culture vials containing quarter-strength PDA and stored at $12^{\circ} \mathrm{C}$. The remaining mycelium was removed from the agar with a sterile scalpel, placed into a 2-ml tube provided with the FastDNA Spin Kit (MP Biomedicals, LLC, Solon, OH), and stored at $-20^{\circ} \mathrm{C}$ until processing.

Total genomic DNA was extracted from the mycelium of each isolate following the manufacture's protocol for fungi. Primers BSRIGS1 and BSRIGS2 (8) were used to amplify the IGS region of each sample as previously described with the following modifications. Each PCR reaction contained $5 \mu \mathrm{l}$ of a 1:100 dilution of mycelial DNA, $300 \mathrm{nM}$ each primer, $0.2 \mathrm{mM}$ dNTPs, $1.5 \mathrm{mM} \mathrm{MgCl} 2,2.5$ units of AmpliTaq Gold polymerase with GeneAmp (Applied Biosystems, Foster City, CA), and $1 \times$ PCR Gold buffer in a $25-\mu$ total volume. Cycling parameters were $95^{\circ} \mathrm{C}$ for $5 \mathrm{~min}, 94^{\circ} \mathrm{C}$ for $3 \mathrm{~min}, 60^{\circ} \mathrm{C}$ for $1 \mathrm{~min}$, and $72^{\circ} \mathrm{C}$ for $2 \mathrm{~min}$, followed by 35 cycles of $94^{\circ} \mathrm{C}$ for $45 \mathrm{~s}, 60^{\circ} \mathrm{C}$ for $45 \mathrm{~s}$, and $72^{\circ} \mathrm{C}$ for $1 \mathrm{~min}$, with a final elongation cycle at $72^{\circ} \mathrm{C}$ for 3 min. Each set of PCR reactions included one isolate of genotype $\mathrm{A}$, one isolate of genotype $\mathrm{B}$, and a negative control (no DNA template). All reactions were performed in an MJ Research PTC-200 thermocycler (MJ Research Inc., Waltham, MA). The genotype of each isolate was determined by comparing the size of the PCR product to a DNA standard and controls following 1\% agarose gel electrophoresis.

Stem samples for q-PCR. Stem tissue (100 mg) from each of the ground bulk samples was added to a 2-ml tube provided with the FastDNA Spin Kit and stored at $-20^{\circ} \mathrm{C}$ until processing. Total genomic DNA was extracted according to the manufacturer's protocol with the following exception. For the initial buffer solution, each tube received $400 \mu \mathrm{l}$ of CLS-Y (for fungi) and $400 \mu \mathrm{l}$ of CLF-VF and $200 \mu \mathrm{l}$ of PPS (for plants). Following extraction, DNA was further purified to remove potential inhibitors using AMPure magnetic beads (Agencourt Bioscience Corp., Beverly, MA) according to the manufacturer's protocol. DNA concentrations were determined using the NanoDrop ND-100 spectrophotometer (Thermo Fisher Scientific, Wilmington, DE) and standardized (4 $\mathrm{ng} / \mu \mathrm{l})$ using ultrapure molecular-grade water.

Multiplex q-PCR assays. Primer/ MGB-probe set BSRqPCRf1-BSRqPCRr1BSRqPCRpb1 (24) and primer/probe set PgsAspF-PgsAspR-PgsAspPR were used in a multiplex q-PCR assay to quantify $P$. gregata $\mathrm{f}$. sp. sojae genotypes $\mathrm{A}$ and $\mathrm{B}$ as previously described (18). The $5^{\prime}$ terminus of BSRqPCRpb1 was labeled with the fluorophore dye 6-FAM and the $3^{\prime}$ terminus was labeled with the minor groove binder (MGB) nonfluorescent quencher MGBNFQ. BSRqPCRpb1 was synthesized by Applied Biosystems. The 5' terminus of PgsAspPR was labeled with the fluorophore dye CAL Fluor Red 610 and the 3' terminus was labeled with the black hole quencher BHQ-2. PgsAspPR was synthesized by Biosearch Technologies (Novato, CA). Primer pairs BSRqPCRf1/ BSRqPCRr1 and PgsAspF/PgsAspR were synthesized by Applied Biosystems.

Each multiplex q-PCR reaction contained $5 \mu \mathrm{l}$ of a $1 \mathrm{ng} / \mu \mathrm{l}$ concentration $(5 \mathrm{ng}$ total) of soil-extracted DNA or $5 \mu \mathrm{l}$ of a 4 $\mathrm{ng} / \mu \mathrm{l}$ concentration (20 ng total) of stemextracted DNA, $450 \mathrm{nM}$ BSRqPCRf1 and BSRqPCRr1, $300 \mathrm{nM}$ PgsAspF and PgsAspR, $100 \mathrm{nM}$ BSRqPCRpb1, $125 \mathrm{nM}$ PgsAspPR, and 1× iQ Supermix (Bio-Rad, Hercules, CA) in a $25-\mu$ l total volume. Cycling parameters were $50^{\circ} \mathrm{C}$ for $2 \mathrm{~min}$ and $95^{\circ} \mathrm{C}$ for $10 \mathrm{~min}$, followed by $40 \mathrm{cy}-$ cles of $95^{\circ} \mathrm{C}$ for $15 \mathrm{~s}$ and $60^{\circ} \mathrm{C}$ for $1 \mathrm{~min}$. All reactions were conducted in a Bio-Rad iCycler iQ multicolor real-time PCR detection system and all samples were run in duplicate. Each set of reactions included one isolate of genotype A (5 ng total), one isolate genotype B (5 ng total), and a negative control (no DNA template). Quantity of DNA of P. gregata f. sp. sojae ('Total') and $P$. gregata f. sp. sojae genotype A present in each sample was determined by absolute quantification based on a standard curve. Standard curves were made from mycelial DNA of $P$. gregata f. sp. sojae genotype A. Standard curves from $5 \mathrm{ng}$ to $5 \times 10^{-5} \mathrm{ng}$ were used for soil samples and standard curves from $20 \mathrm{ng}$ to $20 \times 10^{-4} \mathrm{ng}$ were used for plant samples. Standard curves were present in duplicate in each set of reactions. The quantity of DNA of $P$. gregata $\mathrm{f}$. sp. sojae genotype $\mathrm{B}$ was indirectly determined by subtracting the quantity of $P$. gregata f. sp. sojae genotype A from the Total quantity of $P$. gregata $\mathrm{f}$. sp. sojae (18).

Analyses. All disease severity ratings based on HB values were converted to percentages prior to analysis. From 2000 to 2004, BSR symptom severity data were analyzed as an RCBD by using PROC MIXED (SAS version 9.1; SAS Institute, Cary, NC). In 2005, AUDPCs, incidence of BSR internal stem symptoms, and the maximum number of CFU were analyzed as a split-plot RCBD. Soybean monoculture (accession planted 2000 to 2004) and blocks were treated as random effects. Least significant difference (LSD) comparisons of the means were obtained using the LSMEANS and PDIFF options and letter separations were generated with the PSMIX612 macro by Saxton (31). Comparisons of the mean were conducted at $P \leq 0.05$. Influence of soybean monoculture on the frequency of $P$. gregata f. sp. sojae genotype isolated was 
determined by $\chi^{2}$ analysis with PROC FREQ under the assumption there was a 50/50 likelihood an isolate was either genotype A or genotype B.

The mean quantity of DNA of $P$. gregata f. sp. sojae (Total) and the percentage of genotype $\mathrm{A}$ and $\mathrm{B}$ determined from the Total were used for analysis of $P$. gregata f. sp. sojae population size and genotype composition. Soil data were analyzed as an RCBD with subsampling. Subsamples were defined as the 10 plots established in 2005 within the 38-by-9-m soybean monoculture (Fig. 1). Sub-subsamples were

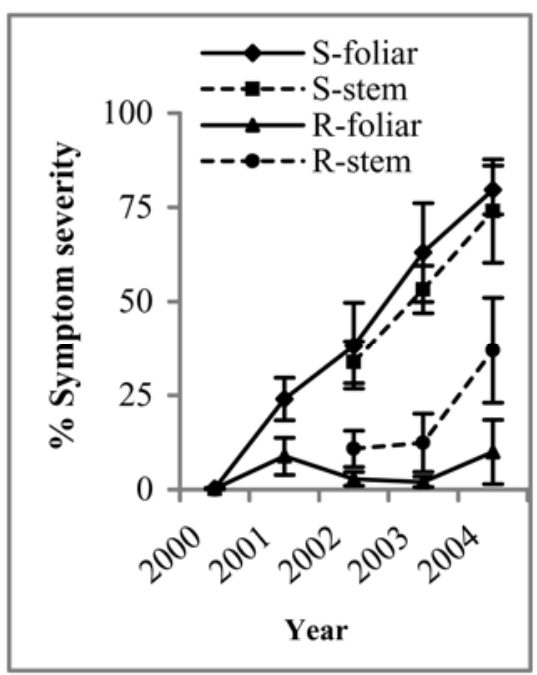

Fig. 2. Brown stem rot (BSR) symptom severity for the monoculture of BSR-resistant (R) or -susceptible (S) soybean accessions from 2000 through 2004. Foliar symptom severity based on the percentage of plot canopy with symptoms of BSR at growth stage R6 (late pod-fill). Stem symptom severity based on the percentage of internal stem discoloration characteristic of BSR at growth stage R7 (beginning maturity). Bars represent one standard error of the mean. defined as the three soil cores taken from within each subsample. Exploratory analysis indicated that block was the only variable considered as a random effect because subsample and sub-subsample did not contribute significantly to the overall variation. Stem data were analyzed as a splitplot RCBD where soybean monoculture was considered as the whole plot and the soybean accession planted in 2005 as the subplot. Block and block-whole plot were considered to be random effects. LSD comparisons of the means were obtained as previously described. Spearman's correlations were calculated with PROC CORR to compare the number of $P$. gregata f. sp. sojae colonies from dilution plating and the results of q-PCR from stem samples.
Contrast statements were used for individual comparisons. Model assumptions were examined with PROC UNIVARIATE and studentized residuals prior to analysis.

\section{RESULTS}

Monoculture establishment-2000 to 2004. In the first year of soybean production, no foliar symptoms characteristic of BSR were observed in either resistant or susceptible soybean accessions (Fig. 2). BSR foliar symptoms were first observed in year two and symptom severity increased in each consecutive year (Fig. 2). Similar results were observed for BSR internal stem symptoms. For each year that soybean plants were monocropped, BSRsusceptible soybean accessions had higher

\section{A $\quad$ BSR-R accession (2005) \\ A 口BSR-S accession (2005) \\ B $\quad$ BSR-R accession (2005) 口BSR-S accession (2005)}

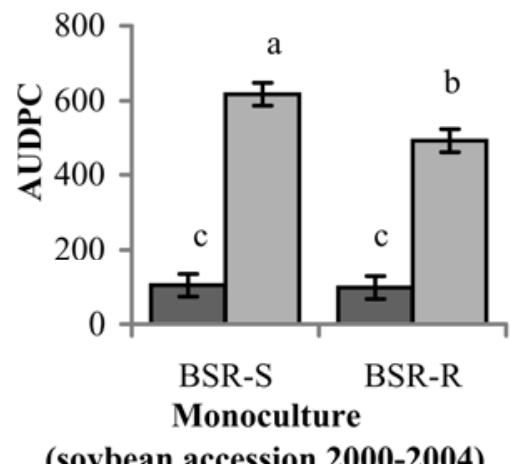

(soybean accession 2000-2004)

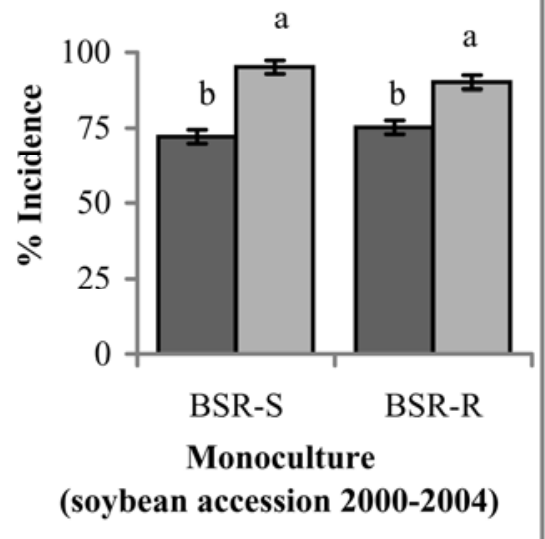

Fig. 3. Brown stem rot (BSR) symptom severity or disease incidence for BSR-resistant or -susceptible soybean accessions planted following the monoculture of either a BSR-resistant or -susceptible accession. A, BSR foliar symptom severity based on area under disease progress curves (AUDPC). B, Incidence of internal stem discoloration characteristic of BSR at growth stage R7 (beginning maturity). Bars represent one standard error of the mean. Means separated by different letters are significantly different at $P=0.05$.

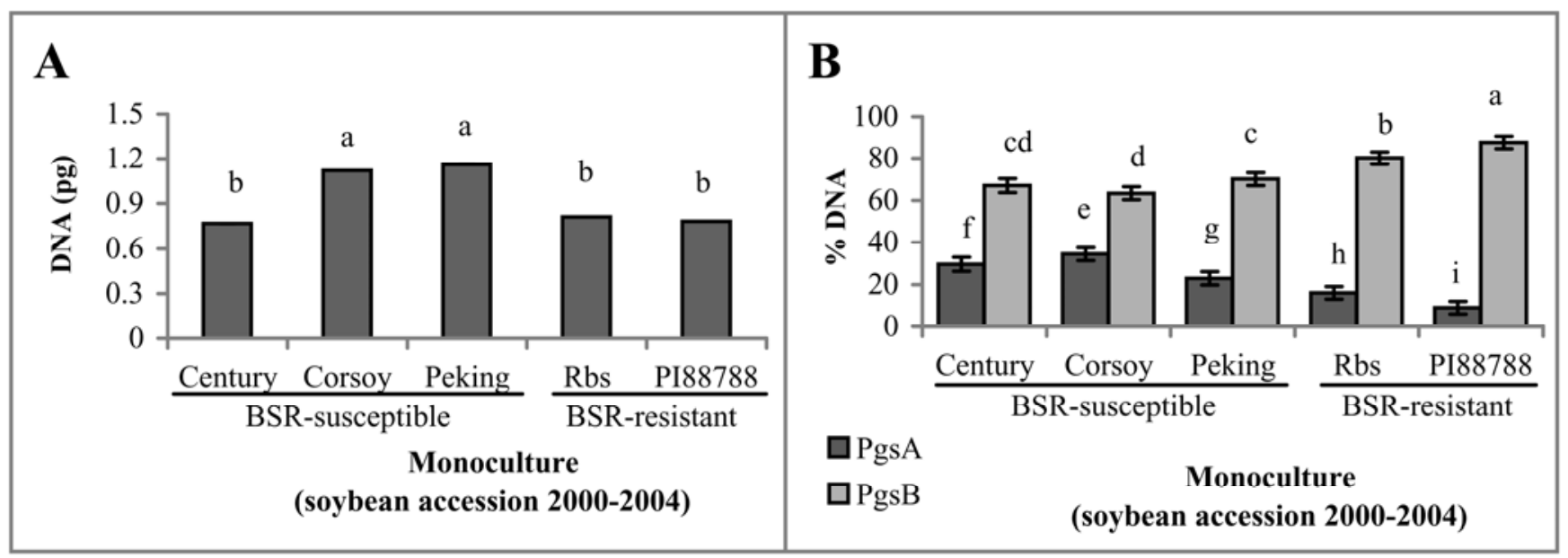

Fig. 4. Quantitative polymerase chain reaction analysis of Phialophora gregata f. sp. sojae (Pgs) population size and genotype composition in soil following the monoculture of a brown stem rot (BSR)-resistant or -susceptible soybean accession. BSR-susceptible accessions are grouped by the presence of cvs. Century, Corsoy, or Peking in their parentage. BSR-resistant accessions are grouped by resistance conferred by an Rbs gene or derived from plant introduction (PI) 88788. A, Population size of P. gregata f. sp. sojae based on the quantity of DNA in $1 \mathrm{~g}$ of soil. B, Percentage of the $P$. gregata f. sp. sojae population identified as genotype A or genotype B. Bars (where visible) represent one standard error of the mean. Means separated by different letters are significantly different at $P=0.05$. 


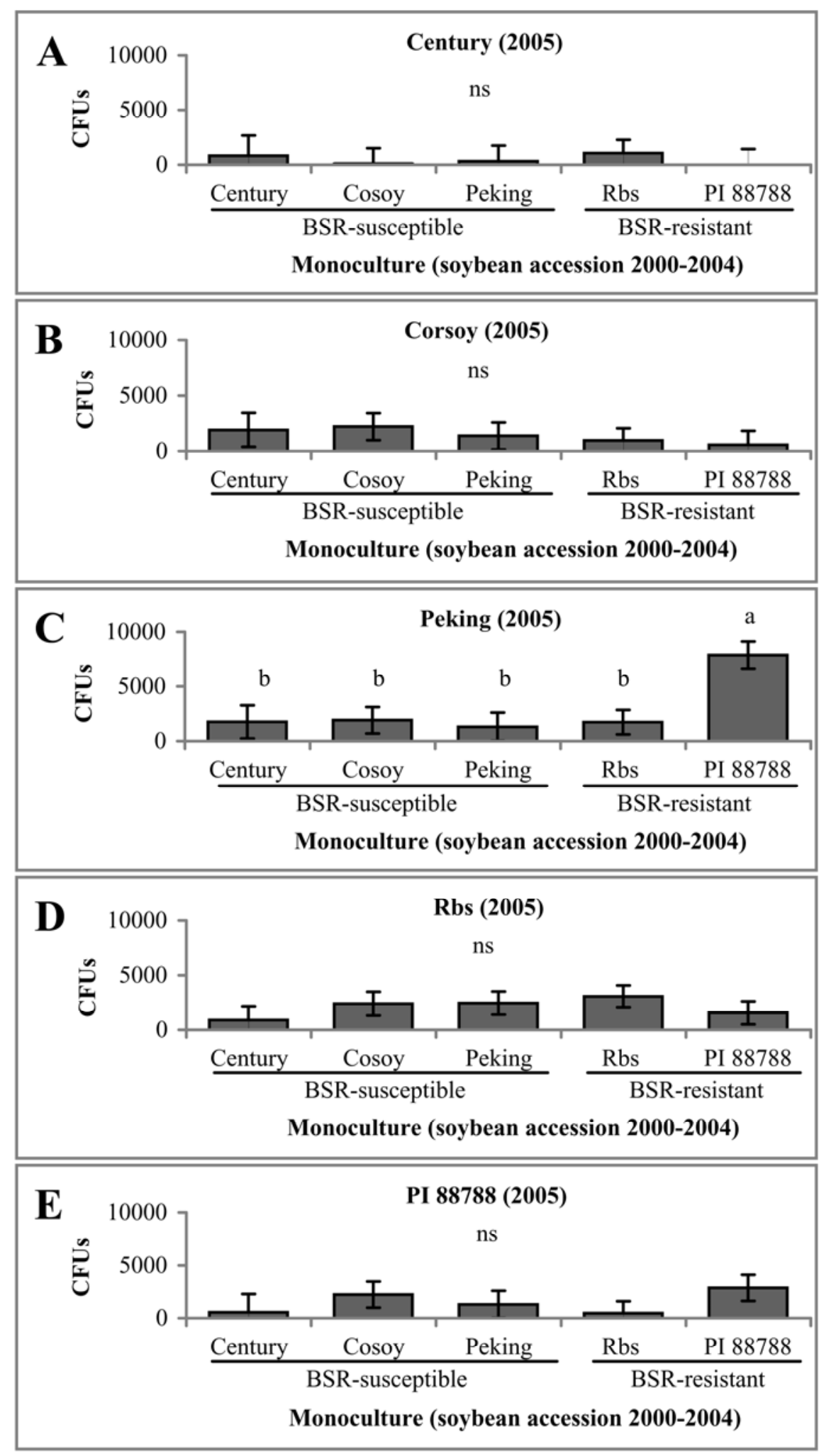

Fig. 5. Population density of Phialophora gregata f. sp. sojae in stems of a brown stem rot (BSR)resistant or -susceptible soybean accession planted in 2005 following the monoculture of either a BSRresistant or -susceptible accession. Population density was assessed as the number of colony-forming units (CFU). Monocultures of a BSR-susceptible accession are grouped by the presence of cvs. Century, Corsoy, or Peking in their parentage. Monocultures of a BSR-resistant accession are grouped by resistance conferred by an $R b s$ gene or derived from plant introduction (PI) 88788. A, BSR-susceptible soybean accession planted in 2005 with cv. Century in its parentage. B, BSR-susceptible soybean accession planted in 2005 with cv. Corsoy in its parentage. C, BSR-susceptible soybean accession planted in 2005 with cv. Peking in its parentage. D, BSR-resistant soybean accession planted in 2005 containing an $R b s$ gene. E, BSR-resistant soybean accession planted in 2005 derived from PI 88788. Bars represent one standard error of the mean. Means separated by a different letter are significantly different at $P=0.05$.
$(P<0.05)$ foliar and internal stem symptom severity than BSR-resistant accessions (Fig. 2).

Assay year 2005. BSR-resistant accessions had lower AUDPCs $(P<0.0001)$ and incidence of internal stem symptoms $(P<$ $0.0001)$ than susceptible accessions following the monoculture of a BSR-resistant or -susceptible soybean accession (Fig. 3). BSR-susceptible soybean accessions had lower AUDPCs $(P=0.04)$ when planted following the monoculture of a BSRresistant accession compared with the monoculture of a BSR-susceptible soybean accession (Fig. 3). Differences in AUDPCs and incidence of internal stem symptoms did not differ among BSR-resistant accessions planted after the monoculture of a BSR-resistant or susceptible soybean accession (Fig. 3). Similarly, incidence of plants with internal stem symptoms did not differ among BSR-susceptible accessions planted after the monoculture of a BSRresistant or -susceptible soybean accession (Fig. 3).

Soil samples: q-PCR. In general, the quantity of $P$. gregata $\mathrm{f}$. sp. sojae DNA detected was greater $(P=0.001)$ in soil following the monoculture of a BSRsusceptible accession than a BSR-resistant accession. However, the quantity of $P$. gregata $\mathrm{f}$. sp. sojae DNA detected in soil following the monoculture of a BSRsusceptible accession with cv. Century in its parentage did not differ from the quantity of $P$. gregata f. sp. sojae DNA detected in soil following the monoculture of a BSR-resistant accession (Fig. 4). Differences in the genotype composition of soil populations of $P$. gregata f. sp. sojae following a soybean monoculture were also observed. The proportion of $P$. gregata f. sp. sojae genotype B DNA in soil was greater than the proportion of $P$. gregata $\mathrm{f}$. sp. sojae genotype A regardless of soybean accession (Fig. 4). However, $P$. gregata $\mathrm{f}$. sp. sojae genotype B DNA was greater $(P<0.0001)$ in soil following the monoculture of a BSR-resistant accession than a BSR-susceptible accession. Also, $P$. gregata f. sp. sojae genotype A DNA was greater $(P<0.0001)$ in soil following the monoculture of a BSRsusceptible accession than a BSRresistant accession (Fig. 4).

As observed with the quantity of $P$. gregata f. sp. sojae DNA, the percentage of $P$. gregata $\mathrm{f}$. sp. sojae genotypes $\mathrm{A}$ and $\mathrm{B}$ DNA detected was also influenced by the genetics of the soybean accession. The percentage of $P$. gregata $\mathrm{f}$. sp. sojae genotype A was the lowest $(P<0.0001)$ and genotype $\mathrm{B}$ the highest $(P<0.0001)$ in soil following the monoculture of a BSRsusceptible accession with cv. Peking in its parentage than in soil following the monoculture of a BSR-susceptible accession with cvs. Century or Corsoy in their parentage (Fig. 4). The percentage of $P$. gregata f. sp. sojae genotype B was higher $(P$ 
$<0.0001)$ and genotype A lower $(P<$ 0.0001 ) in soil following the monoculture of a BSR-resistant accession derived from PI 88788 than in soil following the monoculture of a BSR-resistant accession containing an $R b s$ gene (Fig. 4).

Stem samples: dilution planting, isolate collection, and isolate genotyping. Based on CFU, overall populations of $P$. gregata f. sp. sojae were larger $(P<$ $0.0001)$ for BSR-susceptible soybean accessions than resistant accessions when planted following a resistant or susceptible monoculture. However, BSR-susceptible accessions with cvs. Century or Corsoy in their parentage had lower $(P=0.004)$ populations than susceptible accessions with cv. Peking in their parentage. For BSR-susceptible cultivars with Peking in their parentage, $P$ gregata $\mathrm{f}$. sp. sojae populations were greatest $(P=0.008)$ when planted following the monoculture of a BSR-resistant accession derived from PI 88788 (Fig. 5). No differences were observed in the size of $P$. gregata $\mathrm{f}$. sp. sojae populations from BSR-susceptible accessions with cvs. Century or Corsoy in their parentage when planted following a BSR-resistant or -susceptible soybean monoculture (Fig. 5). Similarly, no differences in $P$. gregata f. sp. sojae population size were observed for BSR-resistant accessions containing an $R b s$ gene or derived from PI 88788 when planted following a BSR-resistant or -susceptible soybean monoculture (Fig. 5).

$P$. gregata f. sp. sojae genotype $\mathrm{B}$ was isolated more frequently $(P<0.0001)$ than genotype A from BSR-resistant accessions planted following a BSR-resistant or -susceptible soybean monoculture (Table 2). $P$. gregata f. sp. sojae genotype $\mathrm{B}$ was also isolated more frequently $(P<0.0001)$ than genotype A from BSR-susceptible accessions planted following a BSR-resistant monoculture (Table 2). No significant difference was observed in the number of isolates of $P$. gregata f. sp. sojae genotype A or genotype B obtained from BSR-susceptible accessions planted following a BSRsusceptible monoculture (Table 2).

There were differences in the number of isolates of $P$. gregata $\mathrm{f}$. sp. sojae genotype B obtained, compared with genotype A, depending on the source of BSR resistance. The ratio of genotype A to B was 1:33 for a BSR-resistant accession derived from PI 88788 planted following the monoculture of an accession also derived from PI 88788 (Table 3). For a BSRresistant accession containing an $R b s$ gene, the ratio of genotype A to B was 1:6 following the monoculture of an accession derived from PI 88788. Similar results were obtained when a BSR-resistant accession contained an $R b s$ gene (1:2) or was derived from PI 88788 (1:11) and was planted following the monoculture of a BSR-resistant accession containing an Rbs gene (Table 3).
Approximately an equal number of isolates of $P$. gregata $\mathrm{f}$. sp. sojae genotypes $A$ and $B$ were obtained from BSRsusceptible accessions regardless of their parentage. The ratio of genotype A to $B$ was 1:1 for BSR-susceptible accessions with Century, Corsoy, or Peking in their parentage planted following the monoculture of a BSR-susceptible accession with

Table 2. Influence of soybean accessions resistant or susceptible to brown stem rot (BSR) on the ratio of Phialophora gregata f. sp. sojae genotypes A and B in stem tissue

\begin{tabular}{|c|c|c|c|c|c|}
\hline \multicolumn{2}{|c|}{ Reaction of soybean accessions to BSR } & \multicolumn{2}{|c|}{$\begin{array}{l}\text { No. of isolates of } \\
\text { P. gregata f. sp. sojae }\end{array}$} & \multirow[b]{2}{*}{ Ratio A:B } & \multirow[b]{2}{*}{$\chi^{2 \mathrm{c}}$} \\
\hline Monoculture $^{\mathrm{a}}$ & Sampled accessions $^{b}$ & Genotype A & Genotype B & & \\
\hline Resistant & Resistant & 44 & 190 & $1: 4$ & $91.1^{* * *}$ \\
\hline Resistant & Susceptible & 64 & 256 & $1: 4$ & $110.2 * * *$ \\
\hline Susceptible & Resistant & 54 & 187 & $1: 4$ & $63.9 * * *$ \\
\hline Susceptible & Susceptible & 164 & 183 & $1: 1$ & $1.04 \mathrm{~ns}$ \\
\hline
\end{tabular}

a Soybean accessions grown in the same location for 5 years (2000-2004) grouped by resistance or susceptibility to BSR. Resistant accessions: BSR 101, IA 2008R, LN92-12033, Dwight, and Jack; susceptible accessions: Sturdy, Corsoy 79, Hardin, Pioneer 9234, and Williams 82.

${ }^{\mathrm{b}}$ Soybean accessions grouped by resistance or susceptibility to BSR planted in 2005 from which isolates of P. gregata f. sp. sojae were obtained. Resistant accessions: BSR 101, IA 2008R, LN9212033, Dwight, and Jack; susceptible accessions: Sturdy, Corsoy 79, Hardin, Pioneer 9234, and Williams 82.

${ }^{c}$ Significance: $* * *$ indicates significance at $P<0.001$ and $\mathrm{ns}=$ no significance.

Table 3. Influence of brown stem rot (BSR)-resistant soybean accessions derived from plant introduction (PI) 88788 or containing one or more Rbs genes on the ratio of Phialophora gregata f. sp. sojae genotypes A and B in stem tissue

\begin{tabular}{|c|c|c|c|c|c|}
\hline \multicolumn{2}{|c|}{ BSR resistant source or genes } & \multicolumn{2}{|c|}{$\begin{array}{c}\text { No. of isolates of } \\
\text { P. gregata f. sp. sojae }\end{array}$} & \multirow[b]{2}{*}{ Ratio A:B } & \multirow[b]{2}{*}{$\chi^{2 \mathrm{c}}$} \\
\hline Monoculture $^{a}$ & Sampled accessions $^{\mathbf{b}}$ & Genotype A & Genotype B & & \\
\hline PI 88788 & PI 88788 & 1 & 33 & $1: 33$ & $30.1 * * *$ \\
\hline PI 88788 & $R b s$ genes & 8 & 46 & $1: 6$ & $26.7 * * *$ \\
\hline$R b s$ genes & PI 88788 & 6 & 65 & $1: 11$ & $49.0 * * *$ \\
\hline$R b s$ genes & $R b s$ genes & 29 & 46 & $1: 2$ & $3.9^{* *}$ \\
\hline
\end{tabular}

a BSR-resistant soybean accessions, grouped by source or genes, grown in the same location for 5 years (2000-2004). BSR-resistant accessions derived from PI 88788: Dwight and Jack; BSR-resistant accessions containing one or more Rbs genes: BSR 101, IA2008R, and LN92-12033.

b BSR-resistant soybean accessions, grouped by source or genes, planted in 2005 from which isolates of P. gregata f. sp. sojae were obtained. BSR-resistant accessions derived from PI 88788: Dwight and Jack; BSR-resistant accessions containing one or more Rbs genes: BSR 101, IA2008R, and LN92-12033.

c Significance: $* *$ and $* * *$ indicates significance at $P<0.05$ and 0.001 , respectively.

Table 4. Influence of brown stem rot (BSR)-susceptible soybean accessions with different parentage on the ratio Phialophora gregata f. sp. sojae genotypes A and B in stem tissue

\begin{tabular}{|c|c|c|c|c|c|}
\hline \multicolumn{2}{|c|}{$\begin{array}{l}\text { Accession in parentage of } \\
\text { BSR-susceptible accessions }\end{array}$} & \multicolumn{2}{|c|}{$\begin{array}{c}\text { No. of isolates of } \\
\text { P. gregata f. sp. sojae }\end{array}$} & \multirow[b]{2}{*}{ Ratio A:B } & \multirow[b]{2}{*}{$\chi^{2 \mathrm{c}}$} \\
\hline Monoculture $^{\mathrm{a}}$ & Sampled accessions ${ }^{b}$ & Genotype A & Genotype B & & \\
\hline Century & Century & 7 & 8 & $1: 1$ & $0.1 \mathrm{~ns}$ \\
\hline Century & Corsoy & 15 & 12 & $1: 1$ & $0.3 \mathrm{~ns}$ \\
\hline Century & Peking & 16 & 16 & $1: 1$ & $0.0 \mathrm{~ns}$ \\
\hline Corsoy & Century & 13 & 13 & $1: 1$ & $0.0 \mathrm{~ns}$ \\
\hline Corsoy & Corsoy & 28 & 22 & $1: 1$ & $0.7 \mathrm{~ns}$ \\
\hline Corsoy & Peking & 29 & 27 & $1: 1$ & $0.1 \mathrm{~ns}$ \\
\hline Peking & Century & 7 & 15 & $1: 2$ & $2.9^{*}$ \\
\hline Peking & Corsoy & 24 & 36 & $1: 2$ & $2.4 \mathrm{~ns}$ \\
\hline Peking & Peking & 25 & 34 & $1: 1$ & $1.4 \mathrm{~ns}$ \\
\hline
\end{tabular}

${ }^{a}$ BSR-susceptible soybean accessions grown in the same location for 5 years (2000-2004) grouped by parentage. BSR-susceptible accession with Century in their parentage: Sturdy; BSR-susceptible accessions with Corsoy in their parentage: Corsoy 79 and Hardin; BSR-susceptible accession with Peking in their parentage: Pioneer 9234 and Williams 82.

b BSR-susceptible soybean accessions planted in 2005, grouped by parentage from which isolates of $P$. gregata f. sp. sojae were obtained. BSR-susceptible accession with Century in their parentage: Sturdy; BSR-susceptible accessions with Corsoy in their parentage: Corsoy 79 and Hardin; BSRsusceptible accession with Peking in their parentage: Pioneer 9234 and Williams 82.

${ }^{c}$ Significance: $*$ indicates significance at $P<0.1$ and ns $=$ no significance. 

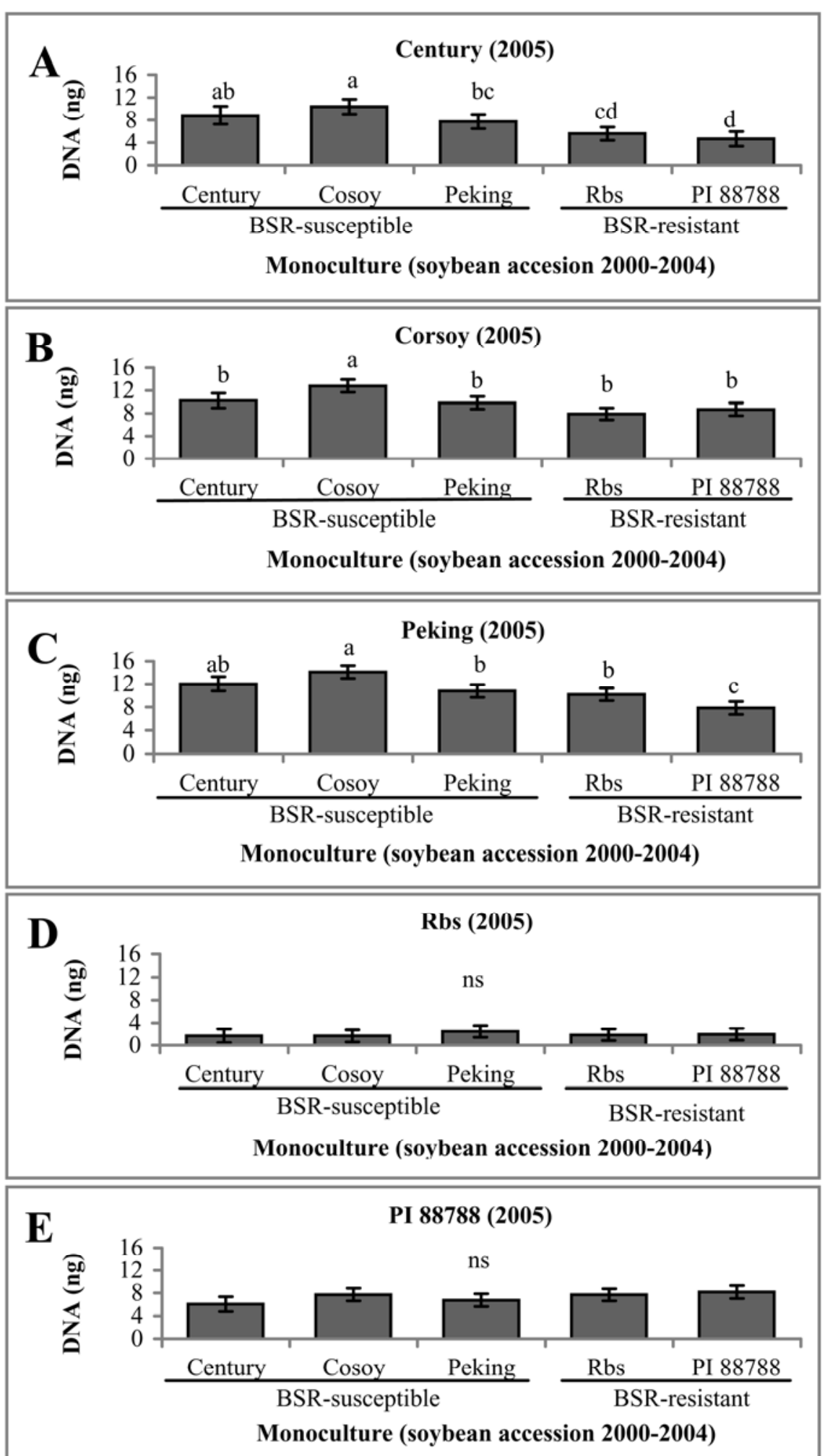

Fig. 6. Quantitative polymerase chain reaction analysis of Phialophora gregata f. sp. sojae population size in stems of a brown stem rot (BSR)-resistant or -susceptible accession planted in 2005 following the monoculture of a either a BSR-resistant or -susceptible soybean accession. The population size of $P$. gregata f. sp. sojae was based on the quantity of DNA detected in $100 \mathrm{mg}$ of ground stem tissue. Monocultures of a BSR-susceptible accession are grouped by the presence of cvs. Century, Corsoy, or Peking in their parentage. Monocultures of a BSR-resistant accession are grouped by resistance conferred by an $R b s$ gene or derived from plant introduction (PI) 88788. A, BSR-susceptible soybean accession planted in 2005 with cv. Century in its parentage. B, BSR-susceptible soybean accession planted in 2005 with cv. Corsoy in its parentage. C, BSR-susceptible soybean accession planted in 2005 with cv. Peking in its parentage. D, BSR-resistant soybean accession planted in 2005 containing an Rbs gene. E, BSR-resistant soybean accession planted in 2005 derived from PI 88788. Bars represent one standard error of the mean. Means separated by a different letter are significantly different at $P=0.05$. stems of a BSR-susceptible accession than in the stems of a BSR-resistant accessions. The quantity of $P$. gregata $\mathrm{f}$. sp. sojae DNA was higher in stems of a BSRsusceptible accession with cv. Century $(P$ $<0.0001)$, Corsoy $(P<0.0001)$, or Peking $(P=0.0005)$ in its parentage when planted following the monoculture of a BSRsusceptible accession versus a BSRresistant accession (Fig. 6). The quantity of $P$. gregata f. sp. sojae DNA in stems of a BSR-resistant accession was unaffected by soybean monoculture; however, more $(P<$ $0.0001)$ DNA was detected in accessions derived from PI 88788 than in accessions containing an $R b s$ gene (Fig. 6).

The percentage of $P$. gregata $\mathrm{f}$. sp. sojae genotype A DNA was greater $(P<0.0001)$ in the stems of a BSR-susceptible accession than in the stems of a BSR-resistant accession. In contrast, the quantity of $P$. gregata f. sp. sojae genotype B DNA was greater $(P<0.0001)$ in the stems of a BSR-resistant accession than in the stems of a BSR-susceptible accession. The proportion of $P$. gregata f. sp. sojae genotypes $\mathrm{A}$ and $\mathrm{B}$ in stems was influenced by the genetics of the soybean monoculture. When a BSR-susceptible accession was planted following the monoculture of a BSR-susceptible accession with cv. Century or Corsoy in its parentage, the percentage of $P$. gregata $\mathrm{f}$. sp. sojae genotype A was greater $(P<0.0001)$ than genotype B (Fig. 7). Conversely, when a BSRsusceptible accession with the cvs. Century or Peking in its parentage was planted following the monoculture of a BSRsusceptible accession with cv. Peking in its parentage, the percentage of $P$. gregata $\mathrm{f}$. sp. sojae genotype $\mathrm{B}$ was greater $(P<0.0001)$ than genotype A (Fig. 7). Following the monoculture of a BSR-resistant accession, the percentage of $P$. gregata $\mathrm{f}$. sp. sojae genotype $\mathrm{B}$ was greater $(P<0.0001)$ than genotype $\mathrm{A}$ in stems of BSR-susceptible accessions. This difference between genotypes B and A was more pronounced following the monoculture of a BSR-resistant accession derived from PI 88788 than an accession containing an $R b s$ gene (Fig. 7).

The proportion of $P$. gregata f. sp. sojae genotype B was always greater than genotype A in stems of a BSR-resistant accession regardless of soybean monoculture (Fig. 7). However, this difference was more pronounced following the monoculture of a BSR-resistant accession than a BSR-susceptible accession (Fig. 7). Spearman's correlation did not indicate a strong association between the results obtained from dilution plating ( rho $=0.27$, $P<0.0001)$ or isolation and standard PCR (genotype A: rho $=0.46, P<0.0001$; genotype B: rho $=0.23, P<0.0001)$ and those obtained with q-PCR.

\section{DISCUSSION}

This study is the first to report on the interaction between soybean genotype and $P$. 
gregata f. sp. sojae genotype in the soil environment. $P$. gregata f. sp. sojae is a residue-borne pathogen that infects soybean plants through the root. Following harvest, colonized root "residue" remains in the field and may serve as an important source of inoculum for BSR in addition to stem residue. Overall, soil populations of $P$. gregata f. sp. sojae were larger following the monoculture of a BSR-susceptible accession compared with the monoculture of a BSR-resistant accession. However, $P$. gregata f. sp. sojae was still detected in soil following the monoculture of a BSRresistant accession and was similar in size to $P$. gregata f. sp. sojae populations following the monoculture of a BSRsusceptible accession with cv. Century in its parentage. $P$. gregata f. sp. sojae soil populations also had a higher proportion of genotype $\mathrm{B}$ than genotype A following the monoculture of a BSR-resistant or -susceptible accession. Nonetheless, significantly more $P$. gregata f. sp. sojae genotype B DNA was detected in soil following the monoculture of a BSR-resistant accession than a BSR-susceptible accession.

Although soil populations of $P$. gregata f. sp. sojae have not been monitored through a crop rotation, rotations are thought to mitigate the effects of BSR by reducing inoculum of $P$. gregata $\mathrm{f}$. sp. sojae (2,34). In 1989, Tachibana et al. (34) reported lower incidence of BSR for a BSR-susceptible cultivar planted following a BSR-resistant monoculture compared with the same cultivar planted following a BSR-susceptible soybean monoculture. From their results, they concluded that long-term cropping of cultivars resistant to BSR could effectively reduce inoculum of $P$. gregata $\mathrm{f}$. $\mathrm{sp}$. sojae and provide the same level of BSR control as crop rotation. The results of the present study do not completely support this conclusion. Instead, our data suggest that the decrease in BSR symptom severity following the monoculture of a BSR-resistant accession may be due more to a change in the genotype composition of $P$. gregata $\mathrm{f}$. sp. sojae populations than a reduction in inoculum.

Earlier studies by Chen et al. (8), Malvick et al. (23), and Meng et al. (25) have provided evidence suggesting that $P$. gregata $\mathrm{f}$. sp. sojae genotypes $\mathrm{A}$ and $\mathrm{B}$ exhibit cultivar preference. These conclusions were based on populations of $P$. gregata f. sp. sojae in stems of soybean accessions collected from fields with histories of soybean production and BSR. In the current study, soybean monocultures based on known host genetics were established in an area never previously cropped to soybean and with no history of $P$. gregata $\mathrm{f}$. sp. sojae or BSR. In addition, the sensitivity and specificity of recently developed qPCR assays were used in conjunction with standard methods to study the interaction between soybean and P. gregata f. sp. so-
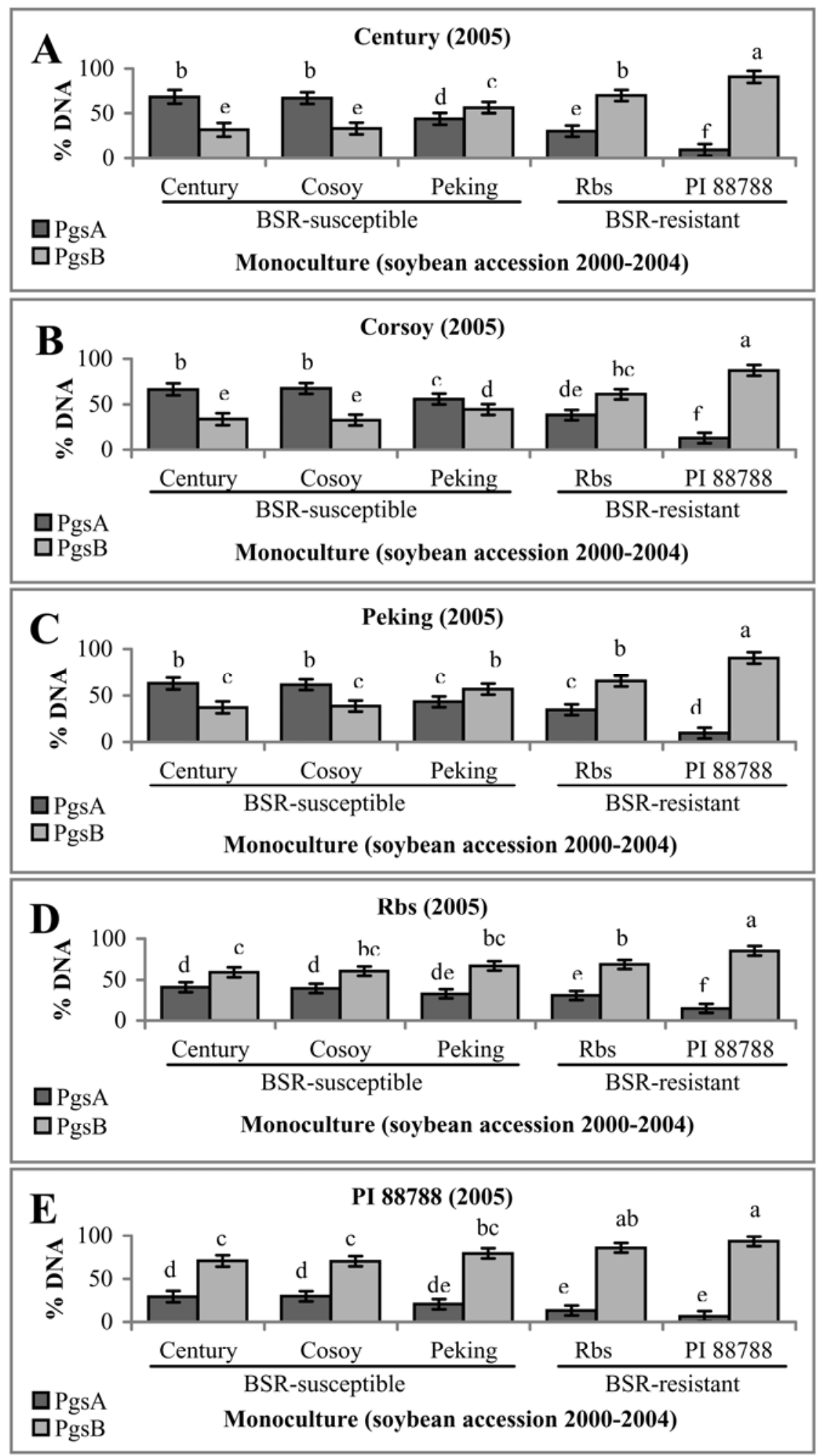

Fig. 7. Quantitative polymerase chain reaction analysis of the genotype composition of Phialophora gregata f. sp. sojae (Pgs) populations in the stems of a brown stem rot (BSR)-resistant or -susceptible accession planted in 2005 following the monoculture of a either a BSR-resistant or -susceptible soybean accession. The genotype composition was determined as the percentage of the Pgs population identified as genotype A or genotype B. Monocultures of a BSR-susceptible accession are grouped by the presence of cvs. Century, Corsoy, or Peking in their parentage. Monocultures of a BSR-resistant accession are grouped by resistance conferred by an $R b s$ gene or derived from plant introduction (PI) 88788. A, BSR-susceptible soybean accession planted in 2005 with cv. Century in its parentage. B, BSR-susceptible soybean accession planted in 2005 with cv. Corsoy in its parentage. C, BSRsusceptible soybean accession planted in 2005 with cv. Peking in its parentage. D, BSR-resistant soybean accession planted in 2005 containing an $R b s$ gene. E, BSR-resistant soybean accession planted in 2005 derived from PI 88788. Bars represent one standard error of the mean. Means separated by a different letter are significantly different at $P=0.05$. 
jae in the soil environment as well as host tissues. Expanding on the previous research of Chen et al. (8), Malvick et al. (23), and Meng et al. (25), the results of this study suggest that both stem and soil populations of $P$. gregata f. sp. sojae are influenced by host genetics.

As observed in earlier studies $(8,23,25)$, BSR-resistant accessions were colonized more by $P$. gregata f. sp. sojae genotype B than genotype A. This inclination toward $P$. gregata $\mathrm{f}$. sp. sojae genotype $\mathrm{B}$ was observed in resistant accessions regardless of monoculture and was considerably more pronounced for accessions derived from PI 88788 than those containing an $R b s$ resistance gene. In general, BSR-susceptible accessions did not show a clear preference for $P$. gregata $\mathrm{f}$. sp. sojae genotype $\mathrm{A}$ as previously observed $(8,23,25)$. Susceptible soybean accessions selected for this study included those with cv. Peking in their parentage. Peking, like PI 88788, is a source of resistance to the soybean cyst nematode (SCN) (10). However, soybean accessions derived from Peking (20) are considered susceptible to BSR while accessions derived from PI 88788 are considered resistant $(20,29)$. When a BSRsusceptible accession was planted following the monoculture of an accession derived from Peking, stems were colonized more by P. gregata f. sp. sojae genotype B than genotype A.

In the north-central United States, the SCN is considered to be the most yieldlimiting pest of soybean (36) and is often found in conjunction with $P$. gregata $\mathrm{f}$. $\mathrm{sp}$. sojae $(32,35)$. Like $\mathrm{BSR}, \mathrm{SCN}$ is predominately controlled with host resistance and the majority $(>95 \%)$ of commercially available cultivars marketed as SCNresistant are derived from PI 88788 or Peking. Results of this study indicate that SCN-resistant accessions, whether resistant or susceptible to BSR, favor $P$. gregata f. sp. sojae genotype B over genotype A. Thus, management practices developed for the simultaneous control of SCN and BSR need to consider the role that $P$. gregata $\mathrm{f}$. sp. sojae genotype plays in disease development and soybean production.

In general, the genotype composition of soil populations of $P$. gregata $\mathrm{f}$. sp. sojae was influenced by soybean genetics in a manner similar to stem populations. However, soil populations of $P$. gregata $\mathrm{f}$. sp. sojae were predominately composed of genotype B regardless of monoculture. Stem populations of $P$. gregata f. sp. sojae suggest that BSR-susceptible accessions with cvs. Century and Corsoy in their parentage tend to favor colonization by $P$. gregata f. sp. sojae genotype A over genotype B. These results indicate that roots may support different populations of $P$. gregata f. sp. sojae than stems (7). Alternatively, these results suggest that there may be differences in the saprophytic fitness of genotypes A and B (1). Currently, experiments are in progress to determine whether P. gregata f. sp. sojae genotypes A and B differ in their saprophytic fitness.

\section{LITERATURE CITED}

1. Abang, M. M., Baum, M., Ceccarelli, S., Grando, S., Linde, C. C., Yahyaoui, A., Zhan, J., and McDonald, B. A. 2006. Differential selection on Rhynchosporium secalis during parasitic and saprophytic phases in the barley scald disease cycle. Phytopathology 96:12141222.

2. Abel, G. H. 1977. Brown stem rot of soybeanCephalosporium gregatum. Rev. Plant Pathol. 56:1065-1075.

3. Adee, E. A., Grau, C. R., and Oplinger, E. S. 1995. Inoculum density of Phialophora gregata related to severity of brown stem rot and yield of soybean in microplots studies. Plant Dis. 79:68-73.

4. Adee, E. A., Grau, C. R., and Oplinger, E. S. 1997. Population dynamics of Phialophora gregata in soybean residue. Plant Dis. 81:199203.

5. Adee, E. A., Oplinger, E. S., and Grau, C. R. 1994. Tillage, rotation sequence, and cultivar influences on brown stem rot and soybean yield. J. Prod. Agric. 7:341-347.

6. Allington, W. B., and Chamberlain, D.W. 1948. Brown stem rot of soybean. Phytopathology 38:1140-1148.

7. Bachman, M. S., and Nickell, C. D. 1999. Use of reciprocal grafting to study brown stem rot resistance in soybean. Phytopathology 89:59-63.

8. Chen, W., Grau, C. R., Adee, E. A., Meng, X. Q. 2000. Molecular marker identifying subspecific populations of the soybean brown stem rot pathogen, Phialophora gregata. Phytopathology 90:875-883.

9. Chen, W., Shi X., and Chen, Y. -C. 2002. Microsatellite markers and clonal genetic structure of the fungal pathogen Phialophora gregata. Mycol. Res. 106:194-202.

10. Diers, B. W., Skorupska, H. T., Rao-Arelli, A. P., and Cianzio, S. R. 1997. Genetic relationships among soybean plant introductions with resistance to soybean cyst nematodes. Crop Sci. 37:1966-1972.

11. Dunleavy, J. M., and Weber, C. R. 1967. Control of brown stem rot of soybeans with cornsoybean rotations. Phytopathology 57:114-117.

12. Eathington, S. R., Nickell, C. D., and Gray, L. E. 1995. Inheritance of brown stem rot resistance in soybean cultivar BSR 101. J. Hered. 86:55-60.

13. Gray, L. E., and Grau, C. R. 1999. Brown stem rot. Pages 28-29 in: Compendium of Soybean Diseases, 4th ed. G. L. Hartman, J. B. Sinclair, and J. C. Rupe, eds. American Phytopathological Society Press, St. Paul, MN.

14. Hanson, P. M., Nickell, C. D., Gray, L. E., and Sebastian, S. A. 1988. Identification of two dominant genes conditioning brown stem rot resistance in soybean. Crop Sci. 28:41-43.

15. Harrington, T. C., and McNew, D. L. 2003. Phylogenetic analysis places the Phialophoralike anamorph genus Cadophora in the Helotiales. Mycotaxon 87:141-151

16. Harrington, T. C., Steimel, J., Workneh, F., and Yang, X. B. 2003. Characterization and distribution of two races of Phialophora gregata in the North-Central United States. Phytopathology 93:901-912.

17. Horsfall, J. G., and Barratt, R. W. 1945. An improved grading system for measuring plant disease. (Abstr.) Phytopathology 35:655

18. Hughes, T. J., Atallah, Z. K., and Grau, C. R. Real-time PCR assays for the quantification of Phialophora gregata f. sp. sojae IGS- genotypes A and B. Phytopathology. In press.

19. Hughes, T. J., Chen, W., and Grau, C. R. 2002. Pathogenic characterization of genotypes A and B of Phialophora gregata f. sp. sojae. Plant Dis. 86:729-735.

20. Hughes, T. J., Kurtzweil, N. C., Diers, B. W., and Grau, C. R. 2004. Resistance to brown stem rot in soybean germ plasm with resistance to the soybean cyst nematode. Plant Dis. 88:761-76.

21. Impullitti, A. E., and Grau, C. R. 2006. Population dynamics of Phialophora gregata in stem residue of a resistant and a susceptible soybean cultivar. Plant Dis. 90:759-764.

22. Kennedy, B. W., and Lambert, J. W. 1981. Influences of brown stem rot and cropping history on soybean performance. Plant Dis. 65:896-897.

23. Malvick, D. K., Chen, W., Kurle, J. E., and Grau, C. R. 2003. Cultivar preference and genotype distribution of the brown stem rot pathogen Phialophora gregata in the Midwestern United States. Plant Dis. 87:12501254.

24. Malvick, D. K., and Impullitti, A. E. 2007. Detection and quantification of Phialophora gregata in soybean and soil samples with a quantitative, real-time PCR assay. Plant Dis. 91:736-742.

25. Meng, X., Grau, C. R., and Chen, W. 2005. Cultivar preference exhibited by two sympatric and genetically distinct populations of the soybean fungal pathogen Phialophora gregata $\mathrm{f}$. sp. sojae. Plant Pathol. 54:180-188.

26. Mengistu, A., and Grau, C.R. 1987. Seasonal progress of brown stem rot and its impact on soybean productivity. Phytopathology 77:15211529.

27. Mengistu, A., Grau, C. R., and Gritton, E. T. 1986. Comparison of soybean genotypes for resistance to and agronomic performance in the presence of brown stem rot. Plant Dis. 70:1095-1098.

28. Mengistu, A., Tachibana, H., and Grau, C. R. 1991. Selective medium for the isolation and enumeration of Phialophora gregata from soybean straw and soil. Plant Dis. 75:196-199.

29. Patzoldt, M. E., Grau, C. R., Stephens, P. A., Kurtzweil, N. C., Carlson, S. R., and Diers, B. W. 2005. Localization of a quantitative trait locus providing brown stem rot resistance in the soybean cultivar Bell. Crop Sci. 45:1241-1248.

30. Pedersen, P. 2004. Soybean growth and development. Iowa State Univ. Ext. Publ. PM1945.

31. Saxton, A. M. 1998. A macro for converting mean separation output to letter groupings in PROC MIXED. Pages 1243-1246 in: Proc. 23rd SAS Users Group Int. SAS Institute, Cary, NC.

32. Tabor, G. M., Tylka, G. L., Behm, J. E., and Bronson, C. R. 2003. Heterodera glycines infection increases incidence and severity of brown stem rot in both resistant and susceptible soybean. Plant Dis. 87:655-661.

33. Tachibaba, H. 1982. Prescribed resistant cultivars for controlling brown stem rot of soybean and managing resistance genes. Plant Dis. 66:271-274.

34. Tachibana, H., Epstein, A. H., and Havlovic, B. J. 1989. Effect of four years of continuous cropping of maturity group II soybeans resistant to brown stem rot on brown stem rot and yield. Plant Dis. 73:846-849

35. Workneh, F., Yang, X. B., and Tylka, G. L. 1999. Soybean brown stem rot, Phytophthora sojae, and Heterodera glycines affected by soil texture and tillage relations. Phytopathology 89:844-850.

36. Wrather, J. A., and Koenning, S. R. 2006. Estimates of disease effects on soybean yields in the United States 2003 to 2005. J. Nematol. 38:173-180. 